\title{
不同气候类型下四川草地土壤有机碳空间分布及 影响因素
}

\section{王丽华 1 , 薛晶月 2,3 谢 雨 $^{2}$ 吴 彦 $^{2 *}$}

${ }^{1}$ 阿坝师范学院, 四川汶川 $623002{ }^{2}$ 中国科学院成都生物研究所, 成都 $610041{ }^{3}$ 中国科学院大学, 北京 100049

摘 要 为探讨不同气候类型下, 草地土壤有机碳含量的分布特征及其影响因素, 以四川省广元市、雅安市和凉山州为研究 地区, 对区域内分层土壤( $0-10 、 10-20 、 20-30 \mathrm{~cm})$ 有机碳含量、氮含量, 根系碳含量、土壤 $\mathrm{pH}$ 值、土壤容重、草地物种组成 和盖度等进行了分析, 探讨不同气候类型下引起土壤有机碳含量变化的主要原因。结果表明: (1) 3 个地区草地总土壤有机碳 含量差异显著, 量差依次为雅安 $>$ 凉山 $>$ 广元, 均出现土壤碳表聚现象, 并随深度增加而递减; (2)雅安草地不同分层土壤有机 碳含量占比与广元和凉山具有明显差异, 其中雅安0-10 $\mathrm{cm}$ 土壤有机碳含量占比显著降低, 而10-20 $\mathrm{cm}$ 占比显著升高, 土壤 有机碳随土层深度增加其降幅与后两者相比略微平缓; (3)广元10-20 cm 土壤有机碳含量与草地丰富度指数正相关, 20-30 cm 土壤有机碳含量与Shannon-Winner指数负相关, 而分层土壤有机碳则与土壤 $\mathrm{pH}$ 值和土壤氮含量正相关, 雅安和凉山分层土 壤有机碳分别与土壤 $\mathrm{pH}$ 值和土壤氮含量正相关; (4)主成分分析显示, 影响 3 个地区草地土壤有机碳总量变化的主要因素是气 候因素, 次要因素是植被因素。

关键词 气候因素; 草地; 土壤有机碳; 分布特征; 相关性分析

王丽华, 薛晶月, 谢雨, 吴彦 (2018). 不同气候类型下四川草地土壤有机碳空间分布及影响因素. 植物生态学报, 42, 297-306. DOI: $10.17521 /$ cjpe.2017.0061

\section{Spatial distribution and influencing factors of soil organic carbon among different climate types in Sichuan, China}

WANG Li-Hua ${ }^{1,2}$, XUE Jing-Yue ${ }^{2,3}$, XIE Yu ${ }^{2}$, and WU Yan ${ }^{2 *}$

${ }^{1}$ Aba Teachers University, Wenchuan, Sichuan 623002, China; ${ }^{2}$ Chengdu Institute of Biology, Chinese Academy of Sciences, Chengdu 610041, China; and ${ }^{3}$ University of Chinese Academy of Sciences, Beijing 100049, China

\section{Abstract}

Aims Spatial distribution and influencing factors of soil organic carbon (SOC) content among different climate types were studied to gain new insights into the estimation and dynamics of SOC.

Methods The study areas are located in the mountain meadow in Guanyuan City, Ya'an City, Liangshan Prefecture of Sichuan Province, China. Plant populations were recorded according to species, number, coverage, meantime, and soil samples (0-10, 10-20, 20-30 cm) were collected and analyzed for SOC content, the carbon content of root, soil $\mathrm{pH}$ value, and soil total nitrogen. The diversity indices for plant community diversity (ShannonWiener index) was also calculated to analyze their relationships with SOC content among different climate types.

Important findings Results showed that: (1) SOC in three sites was significantly different and was in the order of Ya'an > Liangshan Prefecture > Guanyuan, and decreased with soil depth. (2) The percentage of SOC content in each vertical layer out of total SOC was lower in the 0-10 cm layer at Ya'an site than at the other two sites, but was higher than the other two sites in the 10-20 cm layer. (3) At Guanyuan site, SOC content in 10-20 cm was significantly positively correlated with plant species richness index and SOC content in 20-30 cm was negatively correlated with plant Shannon-Winner index, while soil $\mathrm{pH}$ value and soil total nitrogen were significantly positively correlated with SOC content in each layer. At Ya'an site, SOC content in each layer only had positive correlation with soil $\mathrm{pH}$ value, but not with other examined factors. At Liangshan Prefecture site, SOC content in each layer only had positive correlation with soil nitrogen content, but not with other examined factors. (4) Principal

收稿日期Received: 2017-03-16 接受日期Accepted: 2017-07-17

基金项目：中国科学院战略性先导科技专项(XDA05050307)。Supported by the Strategic Priority Research Program of the Chinese Academy of Sciences (XDA05050307).

* 通信作者Corresponding author (wuyan@cib.ac.com) 
component analysis showed that, at Guanyuan, Ya'an and Liangshan Prefecture sites, the total contents of SOC were dominantly affected by climate, followed by vegetation type.

Key words climate factor; grassland; soil organic carbon; distribution characteristics; correlation analysis

Wang LH, Xue JY, Xie Y, Wu Y (2018). Spatial distribution and influencing factors of soil organic carbon among different climate types in Sichuan, China. Chinese Journal of Plant Ecology, 42, 297-306. DOI: 10.17521/cjpe.2017.0061

土壤作为全球陆地生态系统的核心组成部分, 约有 $1500 \mathrm{Gt}$ 碳以有机质的形式存在于土壤中, 土 壤有机碳储量占全球碳库总量的 $2 / 3$ 以上, 而植物 碳库和大气碳库仅为土壤碳库的 $1 / 3$ 和 $1 / 2$ (Fang \& Chen, 2001)。土壤碳库作为陆地生态系统碳循环中 的主体部分, 其微小幅度的变化即会影响大气中碳 的排放量, 改变大气圈中 $\mathrm{CO}_{2}$ 的浓度, 引发温室效 应，从而对全球气候及植物的生长产生影响(Parker et al., 2001)。而气候因素的变化势必会影响土壤中 有机碳的滞留与周转, 从而对土壤碳作为稳定而长 效的碳源物质产生一定的影响, 最终对气候变暖产 生一系列的反馈作用。因此, 揭示土壤有机碳的分 布特征及影响因素是当今生态学、土壤学的研究热 点, 同时对于准确评估全球碳循环及制定应对气候 变化的相应措施具有十分重要的意义(周莉等, 2005)。

土壤有机碳受动植物、微生物残体及其分泌物 等的共同影响, 其含量大小受进入到土壤中的植物 残体量以及土壤微生物分解作用下的损失量共同决 定(Post et al., 1996), 因此土壤碳库大小受气候、植 被、人为、地形等诸多因素的干扰。通常在小尺度 范围上, 地形因素可能是影响土壤有机碳含量呈现 出垂直分布变化规律的主要原因(Pennings et al., 2005; 张宏芝等, 2011), 然而在相对更大的区域尺 度范围内, 气候条件、成土母质、植被类型、地形 条件以及人为因素等的共同影响则可能是决定土壤 有机碳空间分布的重要原因(张勇等, 2009)。在诸多 因素里, 气候变化中太阳辐射和水热条件对土壤有 机碳含量的影响是极为深刻的, 这是因为气候类型 是太阳辐射、降雨、纬度位置等环境因子的综合体 现(Ritchie et al., 2007), 环境因子的差异导致了不 同地区植被类型及地区植被生产力上的差异。从土 壤碳输入和输出的角度来看, 一方面, 植物调落物 的淋溶和分解影响了土壤中碳含量的补给(熊红福 等, 2013), 另一方面, 土壤碳的分解与转化受土壤 微生物分解作用大小的决定, 而微生物活性又受气 候因素(温度、降雨等)的制约(Davidson et al., 2000;
EL-ghamry et al., 2000)。因此, 气候因素的变化对于 土壤有机碳库的变化具有十分重要的影响。我国南 方草地面积占国土面积的 $6.8 \%$ 以上，是一个巨大的 碳库, 而当前关于草地利用方式对土壤有机碳含量 的影响研究较多(唐国勇等, 2010; 陈芙蓉等, 2012), 但关于四川山地不同气候类型下草地土壤有机碳垂 直分布特征及其土壤特性的相关研究较少。

四川省位于中国西南腹地, 介于 $97.35^{\circ}-$ $108.55^{\circ} \mathrm{E}$ 和 $26.05^{\circ}-34.32^{\circ} \mathrm{N}$ 之间, 其地貌复杂, 以 山地为主要特色, 具有山地、丘陵、平原和高原 4 种 地貌类型, 其中四川盆地周缘山地面积广阔, 垂直 山地气候特征明显, 不同地区因气候因素的差异导 致草地土壤有机碳含量及分布特征多而复杂, 因此 结合不同地区气候和植被类型对四川山地草地有机 碳含量分布影响的研究尤为重要。本试验以四川省 内不同气候类型下 (不同经纬度、海拔、降水量及植 被类型 $)$ 的 3 个地区草地为研究样地, 针对其草地表 层土壤有机碳含量 $(0-30 \mathrm{~cm})$ 和垂直空间分布上的 差异及原因进行分析, 为不同气候类型下草地土壤 有机碳储量的估算提供一定参考。

\section{1 研究地区和研究方法}

\section{1 研究区概况}

本次试验研究背景为不同气候类型, 因此样地 选择在四川省内由北向南的广元市、雅安市和凉山 州3个地区。

广元市内选取剑阁县、元坝区、苍溪县作为试 验地, 地理坐标介于 $105.28^{\circ}-107.12^{\circ} \mathrm{E}$ 和 $31.84^{\circ}{ }_{-}$ $32.56^{\circ} \mathrm{N}$, 气候类型均属亚热带季风性湿润气候, 该区域大陆性季风明显，水热条件优越、无霜期长、 气候温和, 所选 5 个样地年平均气温 $16.1{ }^{\circ} \mathrm{C}$, 年降 水量在 $1000 \mathrm{~mm}$ 左右, 年日照时间 1300-1 $400 \mathrm{~h}$, 无霜期220-260天。广元市内所选样地海拔高差控制 在 $200 \mathrm{~m}$ 以内, 平均海拔为 $774 \mathrm{~m}$, 草地类型为山地 疏林草从草地, 主要植被组成为白茅(Imperata $c y$ lindrical)杂类草草从, 土壤类型主要为山地酸性紫 色土。

www.plant-ecology.com 
雅安市内以汉源县为试验地, 位于大渡河中游 两岸, 为四川盆地与西藏高原之间的攀西河谷地带 气候类型, 地理坐标介于 $102.49^{\circ}-102.89^{\circ} \mathrm{E}$ 和 $29.29^{\circ}-29.61^{\circ} \mathrm{N}$, 属川西南山地亚热带气候区, 由 于地形复杂气温垂直变化显著, 从河谷到低山、低 山到中山, 有亚热带、温带、亚寒带之分, 年平均气 温 $17.9{ }^{\circ} \mathrm{C}$, 汉源县降水量严重不均, 集中于5-10月, 干湿交替明显, 且在中山区多, 河谷坝区少, 该地 区受焚风影响, 致使河谷增温气候干燥, 形成特殊 的干热河谷气候。其中汉源县城降水量为 $742 \mathrm{~mm}$ 左 右, 年日照时间 $1475.8 \mathrm{~h}$, 无霜期 300 天。汉源县所 选样地海拔高差控制在 $300 \mathrm{~m}$ 以内, 平均海拔为 $1103 \mathrm{~m}$, 草地类型为干热河谷灌木草丛草地, 草地 以中生或耐旱的旱茅(Schizachyrium delavayi)、黄茅 (Heteropogon contortus)杂类草等植物为主, 土壤类 型主要为紫色土或黄壤。

凉山州内以会理县和会东县作为试验地, 地理 坐标介于 $101.93^{\circ}-102.66^{\circ} \mathrm{E}$ 和 $26.24^{\circ}-26.79^{\circ} \mathrm{N}$, 该 地区属于亚热带西部半湿润气候区, 气候温和, 雨 热同季, 日照充足, 无霜期长, 具有高原、山地立体 气候特点。所选样地年平均气温 $15.7{ }^{\circ} \mathrm{C}\left(15.1{ }^{\circ} \mathrm{C}\right.$ 和
$16.2{ }^{\circ} \mathrm{C}$ ), 年降水量在1 $200 \mathrm{~mm}$ 以上，降水量的 $90 \%$ 以上集中在6-10月，年日照时间 $2300 \mathrm{~h}$ 以上，无霜 期 262 天左右，该地区干湿季节明显，日照充足。会 理县和会东县内所选样地海拔高差控制在 $300 \mathrm{~m}$ 以内, 平均海拔为 $1770 \mathrm{~m}$, 草地类型为山地灌木草 从草地, 主要植被组成为黄茅、野古草(Arundinella anomala)和紫荆泽兰(Eupatorium adenophora)草丛, 土壤类型主要为黄壤或砖红土。

以上 3 个地区在经纬度、年平均气温、年降水量、 年日照时间及海拔等基础数据上存在明显差异, 因 此广元、雅安和凉山所处气候类型有异, 代表了不 同气候类型 $($ 表 1$)$ 。

\section{2 样地设置及样方调查}

2014年7月, 在广元、雅安和凉山选择地形地 貌、草地类型、海拔高差和土壤类型基本一致的草 地上各选择 5 处样点进行样地布设, 每个样点按一 定方向设置 $100 \mathrm{~m}$ 样线, 每隔 $20 \mathrm{~m}$ 布设一个 $0.5 \mathrm{~m} \times$ $0.5 \mathrm{~m}$ 的样方, 每条样线上共设 5 个样方, 每个地区 共计 25 个样方, 样地概况见表 1 。针对每个样点采用 环刀法测定土壤容重, 挖出一个 $1.5 \mathrm{~m} \times 0.5 \mathrm{~m} \times$ $0.3 \mathrm{~m}$ (长 $\times$ 宽 $\times$ 深)的取样坑, 清除样方土壤表面的

表1 样地概况

Table 1 Survey of sampling plots

\begin{tabular}{|c|c|c|c|}
\hline \multirow{3}{*}{$\begin{array}{l}\text { 特征 } \\
\text { Characteristics }\end{array}$} & \multicolumn{3}{|l|}{ 区域地点 Area and site } \\
\hline & 广元市 Guangyuan City & 雅安市 Ya'an City & 凉山州 Liangshan Prefecture \\
\hline & $\begin{array}{l}\text { 剑阁县、苍溪县、元坝区 } \\
\text { Jiange and Cangxi counties; } \\
\text { Yuanba District }\end{array}$ & $\begin{array}{l}\text { 汉源县 } \\
\text { Hanyuan County }\end{array}$ & $\begin{array}{l}\text { 会理县、会东县 } \\
\text { Huili and Huidong counties }\end{array}$ \\
\hline 平均海拔 Mean elevation (m) & $754(616-831)$ & $1103(921-1217)$ & $1770(1651-1917)$ \\
\hline 经纬度 Longitude \& Latitude & $\begin{array}{l}105.47^{\circ}-107.20^{\circ} \mathrm{E} \\
31.84^{\circ}-32.56^{\circ} \mathrm{N}\end{array}$ & $\begin{array}{l}102.82^{\circ}-102.89^{\circ} \mathrm{E} \\
29.29^{\circ}-29.61^{\circ} \mathrm{N}\end{array}$ & $\begin{array}{c}101.93^{\circ}-102.66^{\circ} \mathrm{E} \\
26.24^{\circ}-26.79^{\circ} \mathrm{N}\end{array}$ \\
\hline 地形地貌 Landform & 中山 Middle mountain & 中山 Middle mountain & 中山 Middle mountain \\
\hline 草地类型 Grassland type & $\begin{array}{l}\text { 山地疏林草丛草地 Temperate } \\
\text { woodland meadow type rangeland }\end{array}$ & $\begin{array}{l}\text { 干热河谷灌木草丛草地 } \\
\text { Tropical shrub tussock type rangeland }\end{array}$ & $\begin{array}{l}\text { 山地灌木草丛草地 Mountain shrub } \\
\text { meadow type rangeland }\end{array}$ \\
\hline 主要植被组成 & 白茅杂类草草丛 & 旱茅、黄茅杂类草丛 & 黄茅、野古草、紫荆泽兰草丛 \\
\hline Dominant vegetation & Imperata cylindrica + forbs & $\begin{array}{l}\text { Schizachyrium delavayi }+ \text { Heteropogon } \\
\text { contortus }+ \text { forbs }\end{array}$ & $\begin{array}{l}\text { Heteropogon contortus }+ \text { Arundinella } \\
\text { anomala }+ \text { Eupatorium adenophora }\end{array}$ \\
\hline 草本盖度 Grass coverage & $79.76 \%$ & $78.72 \%$ & $59.9 \%$ \\
\hline 灌木盖度 Bush coverage & $1.25 \%$ & $0.69 \%$ & $0.92 \%$ \\
\hline 土壤类型 Soil type & 紫色土 Purple soil & 紫色土/黄壤 Purple soil/Yellow soil & 黄壤/砖红土 Yellow soil/Laterite \\
\hline 利用强度 Utilize intensity & 轻度利用 Mildly used & $\begin{array}{l}\text { 未利用/轻度利用 } \\
\text { Unutilized/ Mildly used }\end{array}$ & $\begin{array}{l}\text { 轻度/中度利用 } \\
\text { Mildly used/Moderately used }\end{array}$ \\
\hline 气候类型 Climate type & $\begin{array}{l}\text { 亚热带季风性湿润气候 } \\
\text { Humid subtropical seasonal } \\
\text {-wind climate }\end{array}$ & $\begin{array}{l}\text { 亚热带季风性湿润气候(山地干热河谷气候) } \\
\text { Humid subtropical seasonal -wind climate } \\
\text { (The special dry and hot climate) }\end{array}$ & $\begin{array}{l}\text { 亚热带西部半湿润气候 Western } \\
\text { subtropical semi-humid climate }\end{array}$ \\
\hline $\begin{array}{l}\text { 年降水量 } \\
\text { Average annual rainfall (mm) }\end{array}$ & 1000 & 742 & 1200 \\
\hline $\begin{array}{l}\text { 年平均气温 } \\
\text { Average annual air temperature }\end{array}$ & 16.1 & 17.9 & 15.7 \\
\hline $\begin{array}{l}\text { 年日照时数 } \\
\text { Annual sunshine duration (h) }\end{array}$ & $1300-1400$ & 1475 & 2300 \\
\hline
\end{tabular}


植物残留物和杂质, 用规格为高度 $5 \mathrm{~cm}$, 体积为 $100 \mathrm{~cm}^{3}$ 的环刀按照 $0-10 、 10-20 、 20-30 \mathrm{~cm}$ 的深度 从上至下取样, 每层取 5 个重复, 依不同层次取好, 并做好样方标记带回室内 $105{ }^{\circ} \mathrm{C}$ 烘干至恒质量, 并 称质量。

运用目测法，根据经验目测估计样方内各植物 中冠层投影面积和占样方比例, 确定植被高度、盖 度, 并对样方内每一物种的株(丛)数目进行统计, 计算物种丰富度及多样性(采用Shannon-Wiener多 样性指数), 将样方内的植物分物种将地面以上的 所有绿色部分用剪刀齐地剪下, 以便根系和土壤样 品的采集。

丰富度指数: $S=$ 出现在样方的物种数

Shannon-Wiener多样性指数: $S W=-\sum_{i=1}^{S} P_{i} \ln P_{i}$ 式中, $P_{i}$ 为第 $i$ 种的个体数 $n_{i}$ 占所有种个体总数 $n$ 的比 例, $n_{i}$ 为第 $i$ 种的个体数, $n$ 为所有种的个体总数, 即 $P_{i}=n_{i} / n ; i=1,2,3, \cdots, S, S$ 为物种数。

\section{3 样品采集及测定}

各样地中每个样方钻数依据所需土壤样品多少 确定，上层4-6钻混合，下层3-4钻混合，取样时将 样方内土壤表层的残留物和杂质清理干净, 然后用 $5 \mathrm{~cm}$ 直径土钻分 0-10、10-20、20-30 cm共3层依次 取样, 在样方内土钻和根钻间隔取样, 最后将取好 的样品, 按层分装在自封袋中, 并用标签写好样方 号, 放置于自封袋中并带回室内进行指标测定。

土壤有机碳含量(SOC)、土壤全氮含量和植物 根系碳含量测定采用元素分析仪(Vario, Max CN, Elementar Company, Hanau, Germany)测定, 土壤pH 值采用酸度计(Myron L. Company, California, USA) 测定。

\section{4 数据处理}

采用SPSS 19.0 软件对土壤有机碳含量进行单
因素方差分析，比较不同地区和不同土层下土壤有 机碳含量、土壤分层占比、Shannon-Wiener多样性 指数、物种丰富度、土壤氮含量和土壤 $\mathrm{pH}$ 值及其之 间的差异; 采用Pearson相关性分析土壤分层有机碳 含量的影响因子。

\section{2 结果和分析}

\section{1 不同地区草地土壤有机碳含量的变化}

因土层厚度随海拔梯度的变异程度较大，且 0-30 cm土壤有机碳含量对外界环境影响相对敏感, 因此本文只分析了 3 个地区 $0-30 \mathrm{~cm}$ 土壤有机碳含量 及垂直分布情况(表2)。

从草地土壤总有机碳含量来看, 3 个地区土壤总 有机碳含量之间具有显著的差异 $(p<0.05)$, 雅安土 壤总有机碳含量最高 $\left((62.18 \pm 4.40) \mathrm{kg} \cdot \mathrm{m}^{-2}\right)$, 凉山 次之 $\left((51.06 \pm 3.54) \mathrm{kg} \cdot \mathrm{m}^{-2}\right)$, 广元最低((37.91 \pm 3.76) $\left.\mathrm{kg} \cdot \mathrm{m}^{-2}\right)$; 从土壤垂直分布规律来看, 3 个地区 土壤有机碳含量均有表聚现象, 且随土层深度增加 而下降, 表现为0-10 $\mathrm{cm}$ 显著高于10-20 $\mathrm{cm}$ 和20$30 \mathrm{~cm}$ 土壤有机碳含量 $(p<0.05)$, 而后两者之间无 显著差异 $(p>0.05)$; 从不同地区分层土壤有机碳含 量来看, 雅安和凉山表层 $(0-10 \mathrm{~cm})$ 土壤有机碳含量 显著高于广元 $(p<0.05)$, 而在 $10-20 \mathrm{~cm}$ 和 $20-30 \mathrm{~cm}$ 雅安土壤有机碳含量显著高于广元和凉山 $(p<0.05)$, 且后两者之间无显著差异 $(p>0.05)$ 。

\section{2 不同地区分层草地土壤占总土壤有机碳的比例}

研究 3 个地区草地土壤有机碳在垂直剖面上的 分布特征有助于了解不同气候类型下土壤有机碳的 分解和转化规律, 同时也对准确估算土壤碳库具有 一定的指导意义。从图 2 可以看出, 3 个地区土壤有机 碳分配比例随土壤深度的增加均呈降低的趋势, 广 元、雅安和凉山土壤有机碳含量均集中分布于表层 0-10 $\mathrm{cm}$ 处, 分别占总土壤 $(0-30 \mathrm{~cm})$ 有机碳含量的

表2 不同地区 $0-30 \mathrm{~cm}$ 土壤有机碳含量之间的比较(平均值土标准误差, $n=7$ )

Table 2 Soil organic carbon content $(0-30 \mathrm{~cm})$ in different areas (mean $\pm S E, n=7)$

\begin{tabular}{lccc}
\hline 地区 Area & & 土壤有机碳含量 Soil organic carbon content $\left(\mathrm{kg} \cdot \mathrm{m}^{-2}\right)$ \\
\cline { 2 - 4 } & $0-30 \mathrm{~cm}$ & $0-10 \mathrm{~cm}$ & $10-20 \mathrm{~cm}$ \\
\hline 广元 Guangyuan & $37.91 \pm 3.76^{\mathrm{a}}$ & $18.42 \pm 1.61^{\mathrm{Aa}}$ & $11.46 \pm 1.40^{\mathrm{Ba}}$ \\
雅安 Ya'an & $62.18 \pm 4.40^{\mathrm{b}}$ & $25.04 \pm 1.66^{\mathrm{Ab}}$ & $20.80 \pm 1.61^{\mathrm{ABb}}$ \\
凉山 Liangshan & $51.06 \pm 3.54^{\mathrm{c}}$ & $23.44 \pm 1.34^{\mathrm{Ab}}$ & $16.34 \pm 1.56^{\mathrm{Bb}}$ \\
\hline
\end{tabular}

不同小写字母表示各地区间的差异显著 $(p<0.05)$; 不同大写字母表示不同土壤层次间的差异显著 $(p<0.05)$ 。

Different lowercase letters showed significant difference among different areas $(p<0.05)$. Different capital letters showed significant difference among different soil layers $(p<0.05)$. 


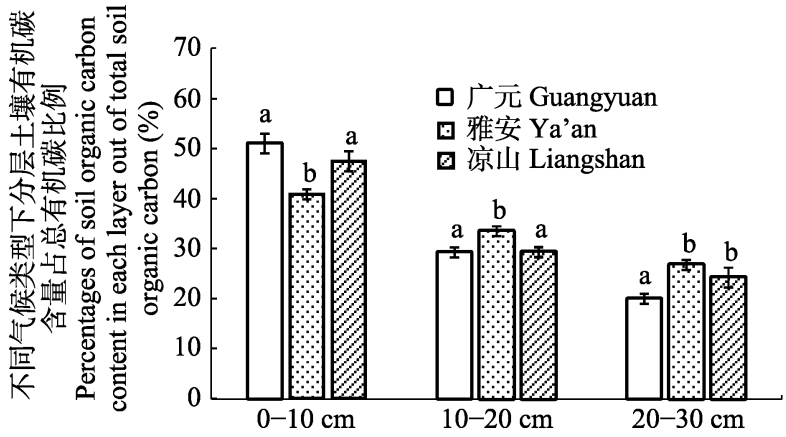

图1 不同地区土壤分层有机碳含量占总有机碳含量比例 (平均值土标准误差, $n=7$ )。不同小写字母表示不同土层间差 异显著 $(p<0.05)$ 。

Fig. 1 The percentages of soil organic carbon content in each layer out of total soil organic carbon in the three sites (mean \pm $S E, n=7)$. Different lowercase letters showed significant difference among different soil layers $(p<0.05)$.

$51.05 \% 、 40.87 \%$ 和 $47.50 \%$, 其中雅安表层土壤有机 碳含量占比显著低于广元和凉山 $(p<0.05)$, 而在 10-20 cm土层中显著高于其余两者 $(p<0.05)$, 且广 元和凉山之间无显著差异 $(p>0.05)$, 但在 20-30 cm 土层中广元的土壤有机碳占比显著低于雅安和凉山, 且后两者之间无显著差异 $(p>0.05)$ 。从不同地区土 壤有机碳分层占比的变化趋势情况来看, 与广元和 凉山相比雅安分层土壤有机碳占比随深度增加降幅 略缓。

\section{3 不同地区草地植被群落特征及土壤相关指标}

从表 3 中可以看出, 雅安的总 $S W$ 和草本 $S W$ 显著 高于广元和凉山 $(p<0.05)$, 而后两者之间无显著差 异 $(p>0.05)$; 雅安灌木 $S W$ 为三地区中最低, 而广元 和凉山之间无显著差异 $(p>0.05)$ 。以上结果说明雅 安物种多样性(主要是草本)大于广元和凉山。然而 从物种丰富度上来看, 广元在三地区中总体、灌木
及草本物种丰富度水平最高, 而雅安除灌木物种丰 富度上与凉山无显著差异外, 其余均明显低于广元 和凉山。

由表3可知, 3 个地区 $0-30 \mathrm{~cm}$ 地下根系碳含量和 土壤 $\mathrm{pH}$ 值依次为雅安 $>$ 凉山 $>$ 广元, 而凉山土壤氮 含量显著高于广元和雅安 $(p<0.05)$, 而后两者间无 显著差异 $(p>0.05)$, 雅安和凉山土壤容重均显著低 于广元 $(p<0.05)$, 且上述两个地区无显著差异 $(p>$ $0.05)$ 。

\section{4 不同地区草地植被群落特征及土壤相关指标 对土壤分层有机碳含量的影响}

从表 4 可以看出, 广元草本和总体 $S W$ 与 20 $30 \mathrm{~cm}$ 土层土壤有机碳含量具有明显的负相关关系 $(p<0.05)$, 而物种丰富度与10-20 cm土壤有机碳含 量有明显的正相关关系; 雅安和凉山土壤有机碳含 量与草地 $S W 及$ 及物种丰富度均无显著相关关系 $(p>$ 0.05)。这说明广元分层土壤有机碳含量受植物群落 特征的影响, 其中广元草本多样性增多不利于深层 (20-30 cm) 土壤有机碳的积累, 而物种丰富度增加有 利于中间层土壤有机碳的积累, 而雅安和凉山草地 植被群落并不是影响土壤有机碳含量的主要因素。

研究结果表明, 3 个地区根系碳含量及土壤容重 与土壤分层碳含量之间均未达到显著相关, 这说明 上述两个指标不是影响土壤分层有机碳含量的主要 因素，而土壤 $\mathrm{pH}$ 值和土壤氮含量在 3 个地区土壤分 层碳含量的影响上存在一定的差异, 其中广元 0-10、10-20、20-30 cm土壤分层碳含量与土壤 $\mathrm{pH}$ 值和土壤氮含量均呈现出极显著的正相关关系 $(p<$ $0.01)$, 在雅安仅与土壤 $\mathrm{pH}$ 值具有显著的正相关关 系 $(p<0.05)$, 而在凉山与土壤氮含量具有极显著的

表3 不同地区植被类型植物群落特征及土壤相关指标

Table 3 Plant community characteristics and related soil parameters in different areas

\begin{tabular}{|c|c|c|c|c|}
\hline \multicolumn{2}{|l|}{ 项目 Item } & \multirow{2}{*}{$\frac{\text { 广元 Guangyuan }}{0.71 \pm 0.20^{\mathrm{b}}}$} & \multirow{2}{*}{$\frac{\text { 雅安 Ya'an }}{0.90 \pm 0.21^{\mathrm{a}}}$} & \multirow{2}{*}{$\frac{\text { 凉山 Liangshan }}{0.61 \pm 0.24^{\mathrm{b}}}$} \\
\hline Shannon-Winner指数 & 总体 Total & & & \\
\hline Shannon-Winner index & 灌木 Bush & $0.30 \pm 0.05^{\mathrm{a}}$ & $0.21 \pm 0.08^{\mathrm{b}}$ & $0.27 \pm 0.07^{\mathrm{ab}}$ \\
\hline \multirow{4}{*}{$\begin{array}{l}\text { 物种丰富度 } \\
\text { Species richness }\end{array}$} & 草本 Grass & $0.19 \pm 0.09^{b}$ & $0.56 \pm 0.17^{\mathrm{a}}$ & $0.15 \pm 0.09^{b}$ \\
\hline & 总体 Total & $20.88 \pm 2.70^{\mathrm{b}}$ & $7.36 \pm 0.42^{\mathrm{a}}$ & $16.28 \pm 1.69^{b}$ \\
\hline & 灌木 Bush & $3.84 \pm 0.42^{\mathrm{a}}$ & $1.72 \pm 0.31^{\mathrm{b}}$ & $2.16 \pm 0.18^{\mathrm{b}}$ \\
\hline & 草本 Grass & $17.04 \pm 2.40^{\mathrm{a}}$ & $5.64 \pm 0.27^{\mathrm{b}}$ & $14.12 \pm 1.70^{\mathrm{a}}$ \\
\hline \multicolumn{2}{|c|}{ 根系碳含量 Root carbon content $\left(\mathrm{kg} \cdot \mathrm{m}^{-2}\right)$} & $0.28 \pm 0.03^{\mathrm{c}}$ & $2.08 \pm 0.18^{\mathrm{a}}$ & $0.70 \pm 0.05^{\mathrm{b}}$ \\
\hline \multicolumn{2}{|l|}{ 土壤pH值 Soil $\mathrm{pH}$ value } & $6.02 \pm 0.18^{\mathrm{c}}$ & $7.13 \pm 0.11^{\mathrm{a}}$ & $6.48 \pm 0.19^{\mathrm{b}}$ \\
\hline \multicolumn{2}{|c|}{ 土壤全氮含量 Soil total nitrogen content $\left(\mathrm{g} \cdot \mathrm{kg}^{-1}\right)$} & $0.10 \pm 0.01^{\mathrm{b}}$ & $0.11 \pm 0.03^{\mathrm{b}}$ & $0.15 \pm 0.01^{\mathrm{a}}$ \\
\hline \multicolumn{2}{|c|}{ 土壤容重 Soil bulk density $\left(\mathrm{g} \cdot \mathrm{m}^{-3}\right)$} & $1.49 \pm 0.01^{\mathrm{a}}$ & $1.37 \pm 0.05^{\mathrm{b}}$ & $1.34 \pm 0.03^{\mathrm{b}}$ \\
\hline
\end{tabular}

不同小写字母表示不同地区间差异显著 $(p<0.05)$ 。

Different lowercase letters showed significant difference among different areas $(p<0.05)$. 
表4 不同地区土壤分层有机碳含量与植被群落特征及土壤指标之间的相关系数

Table 4 The relationship between soil carbon content in each layer and plant community characteristics and soil parameters in different areas

\begin{tabular}{|c|c|c|c|c|c|c|c|c|c|c|}
\hline & & \multicolumn{3}{|c|}{$\begin{array}{c}\text { 广元土壤层 } \\
\text { Guangyuan soil layer }(\mathrm{cm})\end{array}$} & \multicolumn{3}{|c|}{$\begin{array}{c}\text { 雅安土壤层 } \\
\text { Ya'an soil layer (cm) }\end{array}$} & \multicolumn{3}{|c|}{$\begin{array}{c}\text { 凉山土壤层 } \\
\text { Lianghan sool layer (cm) }\end{array}$} \\
\hline & & $0-10$ & $10-20$ & $20-30$ & $0-10$ & $10-20$ & $20-30$ & $0-10$ & $10-20$ & $20-30$ \\
\hline \multirow{3}{*}{$\begin{array}{l}\text { Shannon-Winner指数 } \\
\text { Shannon-Winner index }\end{array}$} & 草本 Grass & -0.359 & -0.251 & $-0.489^{*}$ & -0.208 & -0.140 & -0.184 & -0.320 & -0.118 & 0.055 \\
\hline & 灌木 Bush & -0.170 & -0.225 & $-0.437^{*}$ & 0.268 & 0.191 & 0.167 & -0.272 & -0.077 & 0.059 \\
\hline & 总体 Total & -0.293 & -0.259 & $-0.503^{*}$ & 0.102 & 0.083 & -0.025 & -0.301 & -0.101 & 0.062 \\
\hline \multirow{3}{*}{$\begin{array}{l}\text { 物种丰富度 } \\
\text { Species richness }\end{array}$} & 草本 Grass & -0.092 & $0.666^{*}$ & 0.254 & -0.328 & -0.369 & 0.068 & 0.306 & 0.161 & 0.132 \\
\hline & 灌木 Bush & -0.031 & 0.355 & -0.034 & 0.395 & 0.301 & 0.138 & -0.239 & -0.010 & -0.128 \\
\hline & 总体 Total & 0.077 & $0.645^{*}$ & 0.220 & 0.084 & 0.063 & 0.147 & 0.210 & 0.169 & 0.144 \\
\hline \multicolumn{2}{|c|}{ 根系碳含量 Root carbon content $\left(\mathrm{kg} \cdot \mathrm{m}^{-2}\right)$} & 0.196 & 0.382 & 0.380 & 0.322 & 0.247 & 0.290 & 0.324 & 0.105 & 0.105 \\
\hline \multicolumn{2}{|l|}{ 土壤 $\mathrm{pH}$ 值 Soil $\mathrm{pH}$ value } & $0.527^{* *}$ & $0.606^{* *}$ & $0.717^{* *}$ & $0.517^{* *}$ & $0.477^{*}$ & $0.403^{*}$ & 0.020 & 0.356 & 0.346 \\
\hline \multicolumn{2}{|c|}{ 土壤全氮含量 Soil total nitrogen content $\left(\mathrm{g} \cdot \mathrm{kg}^{-1}\right)$} & $0.867^{* *}$ & $0.860^{* *}$ & $0.834^{* *}$ & 0.239 & 0.103 & 0.027 & $0.677^{* *}$ & $0.681^{* *}$ & $0.634^{* *}$ \\
\hline \multicolumn{2}{|c|}{ 土壤容重 Soil bulk density $\left(\mathrm{g} \cdot \mathrm{m}^{-3}\right)$} & 0.073 & 0.016 & 0.063 & 0.101 & 0.204 & 0.209 & -0.122 & -0.329 & -0.378 \\
\hline
\end{tabular}

${ }^{*}, p<0.05 ; * *, p<0.01$.

表5 不同地区草地各项指标的因子分析结果

Table 5 Factor analysis results of soil physical and chemical factors in different areas

\begin{tabular}{|c|c|c|c|c|c|c|c|c|c|}
\hline \multirow[t]{2}{*}{ 变量 Variable } & \multicolumn{3}{|c|}{ 广元 Guangyuan } & \multicolumn{3}{|c|}{ 雅安 Ya’an } & \multicolumn{3}{|c|}{ 凉山Liangshan } \\
\hline & F1 & $\mathrm{F} 2$ & IC & F1 & $\mathrm{F} 2$ & IC & F1 & $\mathrm{F} 2$ & IC \\
\hline 草本Shannon-Winner指数 Grass Shannon-Winner index & 0.963 & -0.248 & 0.939 & -0.954 & 0.183 & 0.944 & 0.959 & 0.118 & 0.933 \\
\hline 灌木Shannon-Winner指数 Bush Shannon-Winner index & 0.957 & -0.155 & 0.939 & 0.949 & -0.123 & 0.915 & 0.966 & 0.020 & 0.934 \\
\hline 总体Shannon-Winner指数 Total Shannon-Winner index & 0.921 & -0.300 & 0.989 & -0.068 & 0.512 & 0.267 & 0.979 & 0.077 & 0.965 \\
\hline 土壤有机碳含量 Soil organic carbon content $\left(\mathrm{kg} \cdot \mathrm{m}^{-2}\right)$ & -0.097 & 0.981 & 0.972 & 0.388 & 0.504 & 0.405 & -0.333 & 0.871 & 0.870 \\
\hline 土壤全氮含量 Soil total nitrogen content $\left(\mathrm{g} \cdot \mathrm{kg}^{-1}\right)$ & -0.146 & 0.911 & 0.679 & -0.180 & 0.825 & 0.713 & 0.011 & 0.908 & 0.825 \\
\hline 根系碳含量 Root carbon content $\left(\mathrm{kg} \cdot \mathrm{m}^{-2}\right)$ & -0.268 & 0.444 & 0.269 & 0.761 & 0.107 & 0.590 & -0.494 & 0.178 & 0.275 \\
\hline 土壤pH值 Soil $\mathrm{pH}$ value & -0.385 & 0.726 & 0.676 & 0.680 & 0.648 & 0.883 & 0.428 & 0.691 & 0.660 \\
\hline 特征值 Characteristic value & 2.943 & 2.691 & & 3.040 & 1.677 & & 3.350 & 2.112 & \\
\hline 解释异质 Heterogeneous value (\%) & 42.04 & 38.45 & & 43.42 & 23.96 & & 47.86 & 30.18 & \\
\hline 累积解释异质量 Accumulative heterogeneous value (\%) & 42.04 & 80.49 & & 43.42 & 67.39 & & 47.86 & 78.04 & \\
\hline
\end{tabular}

$F 1$, 气候因素; F2, 植物因素; IC, 共同性。

F1, climatic factor; F2, plant factor; IC, intercommunity.

正相关关系 $(p<0.01)$ 。以上结果说明土壤 $\mathrm{pH}$ 值和土 壤氮含量是影响广元土壤分层碳含量的主要因素, 而雅安和凉山分别受土壤 $\mathrm{pH}$ 值和土壤氮含量的影响。

\section{5 影响不同地区土壤总有机碳含量的因素分析}

为分析 3 个地区影响土壤总有机碳含量的主要 影响因素, 将土壤各理化指标和草地群落特征参数 进行分析, 从中选择相关性较强的指标进行主因素 分析，选择群落多样性、土壤有机碳、土壤全氮、 根系碳含量和土壤 $\mathrm{pH}$ 值等7个相关指标进行了因子 分析(表5), 可以看出, 结合数据分析及相关文献, 草本、灌木及总体 $S W$ 属植物因素, 主要受气候因子 的影响, 土壤有机碳和全氮主要受植物因子的影响, 因此将因素一命名为气候因素, 因素二命名为植物 因素, 从 3 个地区因子分析的结果来看, 广元、雅安
及凉山各指标中气候因素均为主要因素, 植物因素 为次要因素。以上结果表明 3 个地区的土壤总有机碳 含量主要受气候因素的影响, 其次为植物因素。

\section{3 讨论}

\section{1 不同气候类型下草地土壤有机碳及空间分布 特征}

我国西部地区草地有机碳储量与纬度之间存在 负相关关系，随纬度的降低，土壤有机碳储量呈降 低的趋势(王绍强等, 2000), 而在海拔500-2 $400 \mathrm{~m}$ 之间的山地地区，草地土壤有机碳储量通常受气温 和降雨的影响而表现出明显的垂直分布特征(Jeny, 1980; Alverz \& Lavado, 1998), 这主要是因为海拔 每增加 $100 \mathrm{~m}$ 后, 温度随之降低0.6-1.0 ${ }^{\circ} \mathrm{C}$, 而降水 
量增加30-80 mm (陈廷舰等, 2014), 此时土壤中水 分蒸发量降低而导致了土壤中水分含量增加, 继而 减少了土壤中微生物的种类和数量。因此, 随着海 拔的上升, 土壤微生物活性降低, 从而抑制了土壤 有机质的分解速率, 最终增大了土壤碳密度。然而 本试验中, 除广元符合上述规律 $($ 土壤总有机碳含 量最低)外, 雅安的草地土壤总有机碳含量却显著 高于凉山, 其原因可能是: 第一, 雅安(汉源县)年平 均气温和降水量在空间上的分异较大(干热河谷区), 导致该区域热量和水分梯度增大, 植物生境多样复 杂, 进而使得该地区草地植物生境扩大, 从而支持 了更多植物物种的生长(冯建孟, 2008), 导致了土壤 有机碳含量的积累; 第二, 凉山过度的人为干扰致 使地表裸露(草地盖度仅 $60.82 \%$ ), 水土流失的可能 性增加, 土壤呼吸增强, 草地土壤有机碳输出大于 输入, 导致了土壤有机碳的固存量降低(Holt et al., 1997; Smolander et al., 1998); 第三, 在样地调查时 发现, 凉山草地中存在大量的有害植物(紫荆泽兰) 入侵的现象, 草地可能发生逆向演替, 使归还到土 壤中的调落物减少, 土壤营养物质降低, 因此草地 土壤有机碳含量降低。

草地土壤有机碳含量受气候、植被、地形、利 用方式及程度等因素的控制, 在区域范围内表现出 一定的尺度效应, 而在垂直空间分布上, 表现为随 土层深度增加呈递减趋势, 且具有明显的表聚现象, 其原因主要与表层土壤中调落物的归还、根系分布 等因素密切相关。通常情况下, 草地表层土壤因地 表凋落物丰富、根系密集, 蓄积了大量有机碳, 随着 土层深度的增加, 根系密度和土壤微生物逐渐减少 等, 致使土壤有机碳含量出现降低趋势(陈廷舰等, 2014)。此外, 植物的生长通常又受到温度、水分、 降水量等气候因素的制约(习丹等, 2013), 水温条件 较好或者空间差异较大的区域都可能提高该地区生 物的多样性(Tilman et al., 1993; Curtis et al., 1999; 冯建孟, 2008, 王长庭等, 2010), 致使其群落物种组 成和根系更为丰富与发达, 调落物和根系分泌物向 土壤中的输入量增大, 进而使土壤有机碳积累增 多。就本试验而言, 3 个地区草地土壤有机碳含量同 样出现了明显的表聚现象, 且随深度增加而降低, 这与前人研究结果(陈廷舰等, 2014)一致, 然而在不 同气候类型下, 草地不同分层土壤有机碳含量占比 及降幅出现了明显的差异, 其中雅安土壤有机碳在
10-20 $\mathrm{cm}$ 占比显著高于广元和凉山, 表现出从表层 到深层土壤有机碳下降略微平缓的趋势, 这可能因 植被类型不同而导致了差异, 其中雅安特殊的河谷 气候使该地区草地旱生植物物种丰富度高, 其植物 根系分布向土壤深处延伸, 从而增加了土壤有机碳 含量在中层的积累, 最终影响了土壤有机碳含量在 各层次的分布特征。

\section{2 不同地区草地土壤剖面有机碳含量的影响因素}

草地土壤有机碳和氮是构成土壤养分的重要组 成部分, 对植物的生长、群落的组成及土壤的结构 等具有重要的影响(门明新等, 2005), 气候因素不仅 是制约草地植被类型及生产力的重要因素, 而且可 通过温度、降雨等因素制约土壤中微生物的数量与 活性, 进而影响土壤中植物残体和调落物的分解等, 最终引起土壤中有机质积累的变化 (Alverz \& Lavado, 1998; 程先富等, 2004)。因此, 草地植被类 型、草地营养物质的数量与有效性均受到气候因素 的制约。植物群落作为植物与环境互作下的产物, 伴随着气候类型的改变, 其物种多样性也随之变化, 不同的环境因子、生境梯度、生态及非生态因子等 因素共同影响了物种的空间分布(王世雄等, 2010)。 本试验中, 雅安草地总有机碳和总 $S W$ 均高于广元 和凉山, 但其物种丰富度指数却为三者最低, 这主 要是因为该地区受干热河谷气候影响, 草地植物物 种单一, 多以中生耐旱且根系较发达的草本植物为 优势种(如旱茅和黄茅等), 偶有耐旱的散生灌木生 长; 而广元相对来说水热条件优越, 草地可能处于 向灌草从草地演替阶段, 因此草地灌木多样性指数 相对较高; 凉山热量丰富, 降雨多且集中, 其海拔 相对较高(平均 $1700 \mathrm{~m}$ )焚风效应减弱, 但由于受人 为干扰较为严重、杂草入侵, 可能导致了草地物种 多样性的降低。草地土壤有机碳在剖面上的垂直分 布与土壤中植物根系的分布有关(陈廷舰等, 2014), 本试验中雅安草地土壤根系碳含量高于广元和凉山, 这与三地区草地土壤中有机碳含量的结果一致。土 壤 $\mathrm{pH}$ 值对草地土壤有机碳的影响主要是通过对土 壤微生物的种类、活性、数量以及限制微生物种类 等方面产生影响。通常认为酸性土壤可以抑制土壤 微生物的活性从而降低有机质的分解速度, 因此, 土壤pH值与土壤有机碳呈反比(张文娟等, 2011)。然 而本试验中, 3 个地区土壤 $\mathrm{pH}$ 值与总土壤有机碳变 化趋势一致, 这可能是因为除土壤 $\mathrm{pH}$ 值外, 气候、 
利用方式等均是影响草地土壤有机碳的重要因素。 土壤氮素作为草地土壤有机质的重要成分, 其含量 大小同样依赖于土壤中植物残体的输入量及土壤微 生物的分解速率, 通常情况下土壤有机碳含量和土 壤全氮均具有正相关性及表聚现象, 且随土层深度 增加而递减, 但其降低幅度因表层植物类型不同而 存在一定的差异(杨金艳和王传宽, 2005)。本试验中, 3 个地区草地土壤全氮含量与有机碳含量不一致, 表现为凉山土壤全氮含量高于雅安和广元, 其原因 可能不单是植被类型的差异, 海拔的增加同样可能 有助于草地土壤氮含量的累积(程先富等, 2004)。前 人研究认为土壤容重越高, 土壤有机碳含量越低, 所以土壤容重通常与土壤有机碳含量呈负相关关系 (Franzluebbers et al., 2000)。本试验结果显示广元土 壤容重与土壤有机碳含量在三地区中为最高值和最 低值, 同样说明土壤容重与土壤有机碳含量之间存 在负相关关系。

草地土壤中有机碳垂直分布不仅受地表植被因 素的影响, 而且受气候因素制约下的土壤微生物活 性的影响, 因此对分层土壤有机碳的影响因素是错 综复杂的(管光玉, 2015)。本试验中, 对3个地区不同 分层草地土壤有机碳含量与 $S W 及 土$ 及壤相关参数(根 系碳含量、 $\mathrm{pH}$ 值、土壤全氮和土壤容重) 进行相关 性分析后发现, 仅广元土壤分层碳含量与草地群落 特征之间具有明显的相关性, 雅安和凉山均未达到 显著效应。这说明广元草地群落物种多样性会影响 深层土壤有机碳含量累积, 原因可能是广元草地处 于次生演替的初期, 其物种竞争加强, 建群种更替 明显, 草地中物种数目增多后导致根系分泌物和调 落物的多样化, 增加了微生物数量和土壤酶活性, 加速了土壤有机质的分解及养分元素的释放, 最终 导致深层土壤有机碳密度降低, 这与李林等(2006) 和崔鸿侠等(2012)认为灌木层和草本层物种多样性 与土壤碳储量呈负相关关系的结果一致。此外, 广 元群落物种丰富度的增加有利于10-20 cm根系分布 量增多, 因此导致该层土壤有机碳含量的累积。雅 安和凉山群落特征与分层土壤有机碳含量均未达到 显著相关水平, 而前人研究(张玲和王承义, 2014)也 有类似结果, 这可能是因为这两个地区草地群落结 构处于稳定状态, 对养分的竞争相对较弱(Carson \& Pickett, 1990), 因此群落物种特征并不是影响这两 个地区分层土壤有机碳含量的主要因素。在对根系
碳含量、 $\mathrm{pH}$ 值、土壤全氮和土壤容重进行相关性分 析研究后发现, 仅有草地土壤 $\mathrm{pH}$ 值和土壤全氮是影 响分层土壤有机碳含量的主要因素, 但在不同地区 影响程度有异, 土壤 $\mathrm{pH}$ 值和土壤全氮是影响广元分 层土壤有机碳含量的主要因素, 而雅安和凉山则分 别受限于土壤 $\mathrm{pH}$ 值和土壤氮含量。这说明, 广元分 层土壤有机碳含量受群落结构、土壤理化性质等综 合环境因子的影响, 而雅安可能因为成土母质、气 候、植被类型较为均匀, 环境因子弱化了其他因素 对它的影响, 而 $\mathrm{pH}$ 值之所以与草地分层土壤有机碳 具有明显的相关关系可能与雅安土壤 $\mathrm{pH}$ 值( $>7$ )较高 导致其微生物活性增强, 因此对草地土壤有机碳含 量造成了明显的影响。同样, 凉山较高的草地土壤 氮含量是驱动土壤养分转化的重要因素, 因此和分 层土壤有机碳含量具有显著的正相关关系。

\section{3 不同地区草地土壤总有机碳含量的影响因素}

不同区域尺度下, 草地土壤有机碳空间变异系 数的影响因子和主控因素具有很大的差异, 因而导 致了不同区域下草地土壤有机碳储量的分异(Wang et al., 2010)。因此加强对区域尺度下草地土壤有机 碳综合影响因素的分析有助于准确估算草地土壤碳 库。气候因素是影响植被类型、地区植被生产力以 及植被固碳速率的主要原因, 而土壤中有机碳输入 的主要来源是植被调落物的分解和淋溶, 因此植物 多样性主要受气候因素的制约, 土壤理化指标主要 受植物因素的影响。本试验中主成分分析结果显示, 广元、雅安和凉山主要受气候因素制约(其方差贡献 率分别为 $42.04 \%$ 、 $43.42 \%$ 和 $47.86 \%)$, 其次受植被因 素的影响(其方差贡献率分别为 $38.45 \%$ 、23.96\%和 $30.18 \%)$ 。这主要是因为气候因素中, 温度和降水是 影响草地植被生长的主要因素, 而土壤中有机碳含 量主要来源于植被的调落物和根系分泌物(谢宪丽 等, 2004; 胡忠良等, 2009), 而本试验中3个地区草 地由于海拔、降水量、经纬度等差异造成了不同的 气候类型, 影响了植被种类的丰富度, 间接影响了 土壤有机碳、氮含量等土壤养分指标。因此, 在 3 个 地区, 气候因素和植被因素共同影响相关指标的大 小, 其中气候因素占主导地位, 植被因素作为次要 因素，共同对草地土壤有机碳含量造成影响。

综上所述, 大区域尺度范围下, 气候因素是影 响草地土壤总有机碳含量的主要因素, 而在小范围 内, 草地不同分层土壤有机碳含量则主要受草地植 
物群落类型、土壤理化性质等相关指标的影响。而 目前有关草地土壤有机碳储量的估算仍然存在不确 定性，一方面是因为不同地区草地土壤构成复杂， 异质性大; 另一方面则是因为不同地区间气候因素 的差异性导致了草地碳储量估算的不准确性。因此, 探讨不同气候类型下草地有机碳含量在空间分布上 的差异对于准确估算草地总碳库具有一定的科学指 导意义。

\section{参考文献}

Alverz R, Lavado RS (1998). Climate organic matter and clay content relationship in the Pampa and Chaco, Argentina. Geoderma, 83, 127-141.

Carson WP, Pickett STA (1990). Role of resources and disturbance in the organization of an old-field plant community. Ecology, 71, 226-238.

Chen FR, Cheng JM, Liu W, Li Y, Chen A, Zhao XY (2012). Effect of disturbances on organic soil carbon in the typical grassland of Loess Plateau. Acta Agrestia Sinica, 20, 298-304，311. [陈芙蓉, 程积民, 刘伟, 李媛, 陈奥, 赵 新宇 (2012). 不同干扰对黄土高原典型草原土壤有机 碳的影响. 草地学报, 20, 298-304, 311.]

Chen TJ, Hu YK, Liu YY, Gong YM, Fang F, Yang XJ (2014). Distribution characteristics and storage of soil organic carbon in the southern slope Altai Mountains. Arid Land Geography, 37, 1231-1239. [陈廷舰, 胡玉昆, 刘妍妍, 公延明, 房飞, 杨秀娟 (2014). 阿尔泰山南坡土壤有机 碳密度的分布特征和碳储量估算. 干旱区地理, 37, 1231-1239.]

Cheng XF, Shi XZ, Yu DS, Fan XZ (2004). Spatial variance and distribution of total nitrogen and organic matter of soil in Xingguo County of Jiangxi, China. Chinese Journal of Applied and Environmental Biology, 10, 64-67. [程先富, 史学正, 于东升, 潘贤章 (2004). 江西省兴国县土壤全 氮和有机质的空间变异及其分布格局. 应用与环境生 物, 10, 64-67.]

Cui HX, Xiao WF, Pan L, Huang ZL, Wang XR, Pang HD (2012). Characteristics of soil carbon storage of Abies fargesii forest in Shennongjia. Scientia Silvae Sinicae, 48(11), 107-111. [崔鸿侠, 肖文发, 潘否, 黄志霖, 王晓 荣, 庞宏东 (2012). 神农架巴山冷杉林土壤碳储量特 征. 林业科学, 48(11), 107-111.]

Curtis RJ, Ferrell GM, Panchabi V (1999). Nutrient effects on stand structure, resorption efficiency, and secondary compounds in everglades saw grass. Ecology, 80, 2182-2192.

Davidson EA, Trumbore SE, Amundson R (2000). Soil warming and organic carbon content. Nature, 408, 789-790.

EL-ghamry AM, Huang CY, Xu JM, Xie ZM (2000). Changes in soil biological properties with the addition of metsulfuron-methyl herbicide. Journal of Zhejiang University (Science), 1, 442-447.
Fang JY, Chen AP (2001). Dynamic forest biomass carbon pools in China and their significance. Acta Botanica Sinica, 43, 967-973.

Feng JM (2008). Spatial patterns of species diversity of seed plants in China and their climatic explanation. Biodiversity Science, 16, 470-476. [冯建孟 (2008). 中国种子植物物 种多样性的大尺度分布格局及其气候解释. 生物多样 性, 16, 470-476.]

Franzluebbers AJ, Stuedemann JA, Schomberg HH, Wilkinson SR (2000). Soil organic C and N pools under long term pasture management in the Southern Piedmont USA. Soil Biology \& Biochemistry, 32, 469-478.

Guang GY (2015). The Study of Community Diversity and Soil Active Organic Carbon Pool Characteristics under Different Utilizations in Alpine Grassland. XingJiang Agricultural University, Ürmüqi. [管光玉 (2015). 不同利用 方式高寒草地群落多样性及土壤活性有机碳库特征研 究. 新疆农业大学, 乌鲁木齐.]

Holt JA (1997). Grazing pressure and soil carbon, microbial biomass and enzyme activities in semiarid Northeastern Australia. Applied Soil Ecology, 5, 143-149.

Hu ZL, Pan GX, Li LQ, Du YX, Wang XZ (2009). Changes in pool sand heterogeneity of soil organic carbon, nitrogen and phosphorus under different vegetation types in karst mountainous area of central Guizhou Province, China. Acta Ecologica Sinica, 29, 4187-4193. [胡忠良, 潘根兴, 李恋卿, 杜有新, 王新洲 (2009). 贵州喀斯特山区不同 植被下土壤C、N、P含量和空间异质性. 生态学报, 29, 4187-4193.]

Jeny H (1980). The Soil Resource: Origin and Behavior. Springer-Verlag, New York. 377.

Li L, Zhou XY, Huang ZL, Wei SG, Shi JH (2006). Study on the relationship between $\alpha$ diversity of plant community and environment on Dinghushan. Acta Ecologica Sinica, 26, 2301-2307. [李林, 周小勇, 黄忠良, 魏识广, 史军 辉 (2006). 鼎湖山植物群落 $\alpha$ 多样性与环境的关系. 生 态学报, 26, 2301-2307.]

Men MX, Peng ZP, Liu YH, Yu ZR (2005). Spatial distribution of soil organic carbon and nitrogen in Hebei Province based on SOTER. Chinese Journal of Soil Science, 36, 469-473. [门明新, 彭正萍, 刘云慧, 宇振荣 (2005). 基 于SOTER的河北省土壤有机碳、氮密度的空间分布. 土 壤通报, 36, 469-473.]

Parker JL, Fernandez IJ, Rustad LE, Norton SA (2001). Effects of nitrogen enrichment, wildfire, and harvesting on forest soil carbon and nitrogen. Soil Science Society of America Journal, 65, 1248-1255.

Pennings SC, Grant MB, Bertness MD (2005). Plant zonation in low-latitude salt marshes: Disentangling the roles of flooding salinity and competition. Journal of Ecology, 93, 159-167.

Post WM, King AM, Wullschleger SD (1996). Soil organic matter models and global estimates of soil organic carbon. In: Powlson DS, Smith P, Smith JU eds. Evaluation of Soil Organic Matter Models: Using Existing Long-Term 
Datasets (Nato ASI Subseries I). Springer-Verlag, Heidelberg. 38, 201-222.

Ritchie JC, McCarty GW, Venteris ER (2007). Soil and soil organic carbon redistribution on the lands cap. Geomorpholosry, 89, 163-171.

Smolander A, Priha O, Paavolainen L, Steer J, Mälkönen E (1998). Nitrogen and carbon transformations before and after clear cutting in repeatedly $\mathrm{N}$ fertilized and limed forest soil. Soil Biology \& Biochemistry, 30, 477-490.

Tang GY, Li K, Sun YY, Zhang CH (2010). Soil labile organic carbon contents and their allocation characteristics under different land uses at dry-hot valley. Environmental Science, 31，1365-1371. [唐国勇, 李昆, 孙永玉, 张春华 (2010). 干热河谷不同利用方式下土壤活性有机碳含量 及其分配特征. 环境科学, 31, 1365-1371.]

Tilman D (1993). Species richness of experimental productivity gradients: How important is colonization? Ecology, 74, 2179-2191.

Wang CT, Long RJ, Liu W, Wang QL, Zhang L, Wu PF (2010). Relationships between soil carbon distribution and species diversity and community biomass at different alpine meadows. Resources Science, 32, 2022-2099. [王长 庭, 龙瑞军, 刘尉, 王启兰, 张莉, 吴鹏飞 (2010). 高寒 草甸不同群落类型土壤碳分布于物种多样性、生物量关 系. 资源科学, 32, 2022-2099.]

Wang DD, Shi XZ, Lu XX, Wang HJ, Yu DS, Sun WX, Zhao YC (2010). Response of soil organic carbon spatial variability to the expansion of scale in the uplands of Northeast China. Geoderma, 154, 302-310.

Wang SQ, Zhou CH, Li KR, Zhu SL, Huang FH (2000). Analysis on spatial distribution characteristics of soil organic carbon reservoir in China. Acta Geographica Sinica, 55, 533-544. [王绍强, 周成虎, 李克让, 朱松丽, 黄方 红 (2000). 中国土壤有机碳库及空间分布特征分析. 地 理学报, 55, 533-544.

Wang SX, Wang XA, Li GQ, Guo H, Zhu ZH (2010). Species diversity and environmental interpretation in the process of community succession in the Ziwu Mountain of Shaanxi Province. Acta Ecologica Sinica, 30, 1638-1647. [王世雄, 王孝安, 李国庆, 郭华, 朱志红 (2010). 陕西子午岭植 物群落演替过程中物种多样性变化与环境解释. 生态 学报, 30, 1638-1647.]

Xi D, Li J, Kuang YW, Xu YM (2013). Variation of soil non-labile carbon under different forest types in Heshan. Journal of Tropical and Subtropical Botany, 21(3), 203-210. [习丹, 李昫, 旷远文, 许伊敏 (2013). 鹤山不 同植被类型土壤惰性碳含量及其季节变化特征. 热带 亚热带植物学报, 21(3), 203-210.]
Xie XL, Sun B, Zhou HZ, Li ZP (2004). Soil carbon stocks and their influencing factors under native vegetations in China. Acta Pedologica Sinica, 41, 688-699. [谢宪丽, 孙波, 周 慧珍, 李忠佩 (2004). 不同植被下中国土壤有机碳的储 量与影响因子. 土壤学报, 41, 688-699.]

Xiong HF, Wang SJ, Rong L, Ni J, Liu XM (2013). Litter fall dynamics of plant communities at different succession stages in karst area of Puding, Guizhou Province of Southwest China. Chinese Journal of Ecology, 32, 802-806. [熊红福, 王世杰, 容丽, 倪健, 刘秀明 (2013). 普定喀 斯特地区不同演替阶段植物群落调落物动态. 生态学 杂志, 32, 802-806.]

Yang JY, Wang CK (2005). Soil carbon storage and flux of temperate forest ecosystems in northeastern China. Acta Ecologica Sinica，25，2875-2882. [杨金艳，王传宽 (2005). 东北东部森林生态系统土壤碳拒量和碳通量. 生态学报, 25, 2875-2882.]

Zhang HZ, Zhu QK, Wang J, Kuang GM, Xie J, Zhao WJ (2011). Soil physical properties of micro-topography on loess slope in North Shaanxi Province. Bulletin of Soil and Water Conservation, 31(6), 55-58. [张宏芝, 朱清科, 王 晶, 广高明, 谢静, 赵维军 (2011). 陕北黄土坡面微地 形土壤物理性质研究. 水土保持通报, 31(6), 55-58.]

Zhang L, Wang CY (2014). Relationship between species diversity and environmental factors of plant community at different succession stages in ecotone of Great Xing'an and Xiaoxing'an Mountains. Forest Engineering, 30(5), 1-5. [张玲, 王承义 (2014). 大小兴安岭过渡区阔叶红 松林次生演替阶段群落多样性指数与环境因子关系. 森林工程, 30(5), 1-5.]

Zhang WJ, Zeng LJ, Wang WQ, Zeng CS (2011). Soil carbon stock of alligator weed in Min River Estuarine wetland. Wetland Science and Management, 7(1), 52-56. [张文娟, 曾路金, 王维奇, 曾从盛 (2011). 闽江河口空心莲子草 土壤碳库研究. 湿地科学与管理, 7(1), 52-56.]

Zhang Y, Shi XZ, Yu DS, Liu XM (2009). Factors affecting variation of soil organic carbon density in YunnanGuizhou-Guangxi Region. Acta Pedologica Sinica, 46, 526-531. [张勇, 史学正, 于东升, 刘秀明 (2009). 滇黔 桂地区土壤有机碳密度变异的影响因素研究. 土壤学 报, 46, 526-531.]

Zhou L, Li BG, Zhou GS (2005). Advances in controlling factors of soil organic carbon. Advances in Earth Science, 20, 99-105. [周莉, 李保国, 周广胜 (2005). 土壤有机碳的 主导影响因子及其研究进展. 地球科学进展, 20 , 99-105.] 